\title{
O POVO DA WEB. ENUNCIAÇÃO DIGITAL E TRANSFORMAÇÃO DA ESFERA POLÍTICA
}

\author{
Lucrecia Escudero Chauvel ${ }^{\mathrm{i}}$
}

Resumo: Uma profunda transformação do espaço público e da esfera política está ocorrendo com uma assombrosa rapidez ligada à mudança tecnológica da mídia e à instalação e consolidação de novas práticas discursivas por parte dos usuários. Estamos diante de um fenômeno complexo no qual se ligam intrinsecamente diferentes dinâmicas, como a temporal instantânea, ou a prática de uma escrita coletiva nas plataformas web de candidatos, as hashtags que alimentam e enquadram as mensagens. A hipótese que se quer desenvolver neste artigo é a de que as transformações que as Novas Tecnologias de Informação e Comunicação (NTIC) produzem têm um tipo particular de relação entre o ator político e o cidadão de novos populismos. O que é coletivo? A quem representa? O povo da web abre caminho para esta nova esfera política. Do ponto de vista de uma sócio-semiótica, as três áreas que estruturam a semiótica produzem no ciberespaço: 1. um laço social centrado nas dimensões patêmicas; 2 . o fazer prático; 3. o dever moral e simbólico. A construção e o triunfo do partido de Emmanuel Macron, La République en Marche!, a partir de seu movimento En Marche! criado em 2016, é um bom exemplo para se discutir as formas em que as NTIC incidem sobre as práticas políticas e na construção da cidadania.

Palavras-chave: Eleições francesas. Estratégias. Enunciação digital. Povo da Web.

\begin{abstract}
A profound transformation of the public space and the political sphere is occurring with a terrible swiftness linked to the technological changes of the media and to the installation and consolidation of new discursive practices on the part of the users. We are before a complex phenomenon in which different dynamics, such as the instantaneous temporality, or the practice of collective writing on the Web platforms of candidates, and the hashtags that feed and frame the messages are intrinsically connected. The hypothesis that we intend to develop in this article is that the transformations that the New Technologies of Information and Communication (NTICS) produce have a particular type of relation between the political actor and the citizen of new populisms. What is collective? Whom does it represent? The people of the Web open the way for this new political sphere. From a socio-semiotic standpoint, the three areas that structure semiotics produce in cyberspace: 1 . a social bond centered on the pathos dimensions; 2. the making practical; 3. the moral and symbolic duty. The construction and triumph of Emmanuel Macron's party, La République en Marche!, as a result of his movement En Marche! created in 2016, is a good example to discuss the ways in which NTICs affect the political practices and citizenship construction.
\end{abstract}

Keywords: French elections. Media strategies. Digital enunciation. People of the Web.

\footnotetext{
'Docente da Universidade de Lille, França. Email: lescuderochauvel@gmail.com.
} 
EID\&A - Revista Eletrônica de Estudos Integrados em Discurso e Argumentação, Ilhéus, n. 16 esp. "Discurso e argumentação na política latino-americana, set.2018.

\section{Condições da midiatização}

Não há democracia de massa sem a comunicação de massa. A esta afirmação de Dominique Wolton (1999), corresponderia a pergunta que nos fazemos ao longo deste artigo: como as NTIC influenciam nos sistemas democráticos e que tipo de construção de cidadania isso implica? A comunicação política, uma prática social e, simultaneamente, um campo de estudos sobre a regulação da sociedade, está estreitamente ligada à modernização do espaço público e ao papel dos meios de construção de uma nova arena social, na qual o político se torna espetáculo e se põe em cena. A dimensão teatral desse tipo de comunicação, que aparece amplificada pela televisão e seu dispositivo audiovisual, inclui os problemas da argumentação, da persuasão e da manipulação - (resquícios?) da retórica ciceroniana e sofista-, mas se insere em um cenário relativamente recente: o da midiatização, entendida como aqueles processos que têm os meios como agentes principais de socialização, contribuindo ativamente para construir nossa percepção do mundo circundante.

A invasão dos meios no cenário político produziu novos efeitos na cidadania, mas também, no ator político: adaptar-se a diferentes lógicas de fragmentação de mensagens que deverão caber no tempo de rádio ou de televisão; a abolição de um sistema argumentativo intrínseco da palavra escrita, mas relativamente maior e mais complexo para a televisão, que deve se conformar com outro tipo de causalidade não contextualizada. A agenda dos meios influi sobre o tempo político com sua curta temporalidade; esta nova esfera política é, em síntese, um espaço midiático pressionado pelo tempo. Atores políticos, práticas discursivas e o papel dos meios tradicionais estão articulados no espaço público produzindo escândalos, revelações, denúncias, desinformações ou contribuindo, também, para a construção da cidadania.

A reflexão de Harmut Rosa (2010, p. 214 ss) sobre a percepção da aceleração do tempo é, a meu ver, um elemento fundamental para entender a natureza do desenvolvimento da midiatização dos processos políticos e suas consequências. Para o discípulo de Habermas, este cenário de "multitemporalidade" das NTIC rompe com a linearidade do tempo e do evento - um início, meio e fim - e mostra à contraluz, que a aceleração tem consequências culturais profundas. 
EID\&A - Revista Eletrônica de Estudos Integrados em Discurso e Argumentação, Ilhéus, n. 16 esp. "Discurso e argumentação na política latino-americana, set.2018.

Esta característica determinante não se explicará sem o processo de midiatização que se estabelece em meados do século passado. A percepção de um tempo aberto e sua articulação com a ação política é o que facilita a instalação de um novo valor quase hegemônico, o de mudança, em contraposição ao de permanência ou tradição.

Não é casual que o nome da coalizão partidária que governa, atualmente, a Argentina seja, precisamente, Cambiemos e a forma da construção política de Macron tenha sido o Movimento. Ao advento da sociedade da informação e da transparência, a mundialização responderia a uma mudança qualitativa da percepção de uma temporalidade imbricada. As consequências políticas das quais o ator político já não poderá subtrair-se está de mãos dadas com a constituição das agendas globais. A circulação imediata e global na Web contribui para produzir uma mudança no limite do tolerável/intolerável como mostrou o fenômeno global Me too ${ }^{1}$, inaugurando a era dos direitos sociais no ciberespaço. Sem cair em uma nova dicotomia entre apocalípticos e integrado em tempos de internet, a modernidade avançada irá produzir efeitos muito concretos na constituição do cidadão, seus objetivos, aspirações, responsabilidades, deveres, direitos e reivindicações vão redefinir em profundidade a esfera política configurando um novo território.

A conectividade, por sua parte, se torna muito veloz e, sobretudo, barata, chegando a cobrir audiências globais e mercados planetários. Nasce, também, o conceito de Milenials uma categoria etária-discursiva, que delimita um alvo específico, não somente integrado por um setor social, mas também - e esta é a novidade, por uma prática emissora-receptora específica, - pela comunicação e pela interação via internet com um mediador técnico que se tornará um verdadeiro fetiche do século XXI: o celular inteligente com tecnologia Android.

\section{A transformação da visibilidade}

Thompson (1995, p.118ss) sinalizou a importância crucial da evolução técnica dos meios audiovisuais tradicionais na aproximação entre o homem político e o cidadão. Pensemos na dramática intervenção de Charles De Gaulle

\footnotetext{
$1 \mathrm{NT}$ : Me too, referente a \#metoo que marcava as denúncias, nas redes sociais, de pessoas que sofreram abusos sexuais. Tal movimento foi desencadeado em outubro de 2017, após atrizes de Hollywood terem denunciado por crime de estupro e agressão sexual o produtor cinematográfico americano Harvey Weinstein.
} 
EID\&A - Revista Eletrônica de Estudos Integrados em Discurso e Argumentação, Ilhéus, n. 16 esp. "Discurso e argumentação na política latino-americana, set.2018.

em junho de 1942, graças a BBC de Londres, para convocar a resistência francesa que o ouviu em todos os lugares do país, após a ocupação alemã; ou os discursos de Eva Perón, com sua voz rouca e poderosa, gravados no imaginário coletivo dos argentinos; ou o famoso debate televisivo entre John F. Kennedy e Richard Nixon, que inaugura a era do marketing político moderno. Era o apogeu da radiodifusão e do broadcasting. Esta midiatização incipiente está ligada ao poder político, ou seja, ligada a um dispositivo de visibilidade e influência.

Nesta proto-mediação política, a importância dos comícios e de encontros em assembleias ou comitês em geral é primordial. É certo que essa comunicação cara a cara foi, se recordarmos, hegemônica desde a república ateniense até a aparição da mídia - a evolução da tecnologia é curta e relativamente recente - e deu passo para a comunicação midiatizada, na qual o homem político e a mídia começam a precisar um do outro. Thompson (1995) chama isso de ilusão da co-presença: visíveis uns aos outros no interior da esfera político-midiática, em que o meio tradicional, jornal, rádio, TV, cinema, é um instrumento de amplificação dessa visibilidade. Porém, com a instalação das NTIC e desde a invisibilidade à hipermidiatização atual, se modificou em profundidade não só a prática política, mas como obviamente também as condições de sua recepção.

De fato, não só o político adapta sua atividade e sua agenda ao timing da mídia, mas também essa relação se tornou constitutiva da esfera política (Thompson, 1995, p.120) porque reconfigura, também, o espaço privado, codifica o que se pode mostrar, produzindo na recepção, a ilusão de um espaço transparente, sem mediações.

\section{A gestão da visibilidade: gêneros e formatos}

Com os meios tradicionais, instala-se, então, uma nova visibilidade que produz, em troca, um apagamento de fronteiras, o nascimento de novas paixões sociais como "o voyeurismo" (ESCUDERO CHAUVEL, 2000) e a emergência de gêneros híbridos: entre a informação e o entretenimento, entre a telerrealidade e o docudrama, séries de televisão, encenações e reconstruções, habilitam uma gama de programas e formatos (ESCUDERO CHAUVEL; GARCIA RUBIO, 2007). A relação esfera pública - esfera privada esfera pública terá também repercussões quando surgirem novas lideranças vindas da sociedade civil - um "de fora" do mundo político. A gestão da 
EID\&A - Revista Eletrônica de Estudos Integrados em Discurso e Argumentação, Ilhéus, n. 16 esp. "Discurso e argumentação na política latino-americana, set.2018.

visibilidade e da reatividade estão no coração das estratégias de comunicação políticas atuais, talvez sendo a principal tarefa. Não só como rotina responder à imprensa, fotografar, fazer coletivas de imprensa, aparecer na televisão tuitar e "postear" -, mas também, como substituição às formas tradicionais de contato e do fazer político.

Essa hipervisibilidade submete o político a um stress permanente, porque todo o privado se torna uma construção simbólica de si mesmo em público. O privado acompanha o público já como um dos ADN do político e este deverá se adaptar aos múltiplos formatos da natureza comunicacional, como os talk shows, entrevistas, participações em noticiários de horário nobre, entrevista em rádios, crônicas humorísticas, interação em redes sociais e tudo ao vivo.

\section{Semioses e midiatização}

Os processos de midiatização são poderosos agentes de homogeneização e de aceleração. Homogeneização porque um conjunto de formatos televisivos, uma vez testada a sua eficácia, se repetirão em diferentes canais ou em diferentes países, como o caso das transmissões políticas em série. Uma fórmula de campanha exitosa se repetirá e será adaptada a outros contextos, como foi o caso da campanha de Obama e a utilização das redes sociais, tornando-se um estudo de caso.

Por sua parte, a midiatização se tornou um conceito guarda-chuvas: pode significar interface técnica entre os meios e a sociedade, ou um mecanismo técnico-discursivo que atravessa a integralidade do dispositivo enunciativo do meio que usa ou não um canal tradicional - como o rádio, a televisão, a internet, a imprensa, etc. O conceito de midiatização vai integrarse, a meu ver, ao de globalização e de convergência tecnológica, sendo que estão intrinsecamente ligados formando a tríade definitiva da modernidade avançada. É um conceito historicamente ligado ao desenvolvimento tecnológico dos meios, é dizer que aparece como conceito explicativo em um determinado momento do desenvolvimento dos meios de massa. Não havia midiatização na época de Luís XVI - como não havia moda na Roma Antiga embora existisse a imprensa de opinião, as moedas e os retratos e, na Roma Antiga, uma mudança no penteado das mulheres mostrava o grau de pertencimento a uma classe. É necessário dar certas condições de produção técnico-discursiva e, para o caso da moda, tão estritamente ligada aos 
EID\&A - Revista Eletrônica de Estudos Integrados em Discurso e Argumentação, Ilhéus, n. 16 esp. "Discurso e argumentação na política latino-americana, set.2018.

fenômenos midiáticos, uma indústria de produção de bens e serviços como no século $X I X$.

Figura 1 - Instrucciones a los usuarios: "Si está en el móvil, hay que conectarse a Facebook desde Safari para que los Likes funcionen"”

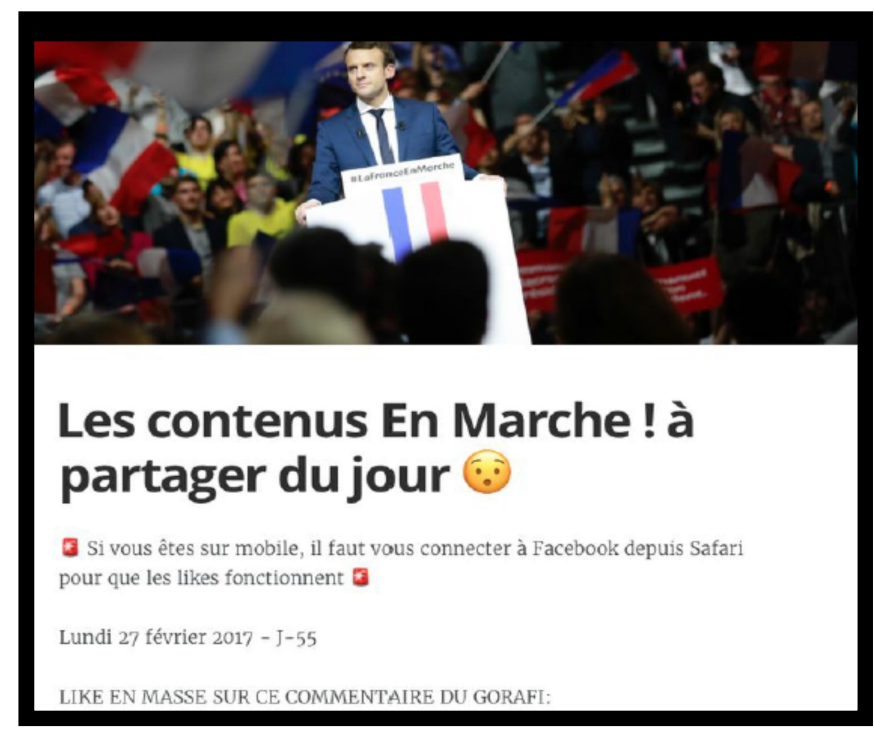

Roberto Igarza (IGARZA, 2008, p. 14ss) falará de uma transformação que implica basicamente "a imersão rápida de todos os agentes sociais em uma etapa avançada de digitalização". A digitalização é para o autor a condição necessária para a midiatização atual. Longe de ser um conceito abstrato, as eleições francesas nos mostraram como muitas estratégias políticas de tomada de contato, informação e seguimento seriam impossíveis sem o público altamente digitalizado, para os quais a interatividade é um elemento chave.

De que natureza é esta midiatização digital? A semiótica vem estudando, com profundidade, o conceito de midiatização e o de dispositivo aplicado às análises dos meios tradicionais e da web (VERON, 1981; 1987; TRAVERSA, 2014; SCOLARI, 2008, 2018; FERNÁNDEZ, 2018). A construção de um leitor modelo (ECO, 1979), com uma atividade solicitada e cooperante é central na recepção dos meios. Como bem mostrou Scolari(2018), é o conceito de interface que se torna chave. Os receptores interagem entre si nas plataformas, transformando os conteúdos que por sua vez retroalimentam as equipes de

\footnotetext{
2 As figuras estão no site: https://www.larepubliqueenmarche; https://www.facebook.com/EmmanuelMacron. Acesso em: 15 ago.2017. Os discursos completos constam no site, livres de direitos.
} 
EID\&A - Revista Eletrônica de Estudos Integrados em Discurso e Argumentação, Ilhéus, n. 16 esp. "Discurso e argumentação na política latino-americana, set.2018.

políticos, produzindo um processo de retroalimentação constante. Uma semiose virtual ilimitada, mudando, simultaneamente, o estatuto do receptor e do político.

A conjunção simultânea do usuário da web com o leitor dos conteúdos sintetizada na categoria de prosumer $^{3}$ agrega a prática do cidadão que adere virtualmente ('curto o conteúdo que gosto'), formando também uma tríade de circulação de sentido. Essa prática, colocada em um lugar de recepção, levar-nos-ia ao lugar comum de que é exclusivamente a interatividade o traço distintivo central e determinante do processo, mas em realidade a consequência maior é que esta romperia com a linearidade da proposta e da causalidade que o político propõe, historicamente unidirecional.

Essa prática de intercâmbio de mensagens e de interação comunicativa midiatizada pela web corresponde-se, perfeitamente, com a emergência de um ator social ativo, permanentemente solicitado, individualizado com nome, sobrenome e foto. A hiper-subjetivação, contrapartida da globalização anônima (sujeitos cada vez mais atomizados, mas virtualmente conectados), encontra discursivamente seu suporte expressivo na Web 2.0.

$\mathrm{Na}$ realidade, não poderíamos dizer que esses processos são unidirecionais (a percepção do sujeito comunicando-se diretamente com o centro do poder político ou do dispositivo), mas que se produz uma sorte de prática coletiva na qual o usuário-cidadão compartilha a ilusão e a certeza de pertencer a um coletivo maior que o contém e o retroalimenta: o povo da Web. Este sentimento de pertencimento vai incidir, necessariamente, sobre a prática democrática de representação e delegação. Se na era do broadcasting Dominique Wolton (1999) podia afirmar que não existe democracia de massa sem meio de massa, poderíamos dizer que atualmente a participação cidadã se expressa não somente através do voto, mas também, através do comentário na internet ou no mural do Facebook do político.

Essas estratégias participativas da parte do emissor que incita a tomada de contato, mas recolhidas por sua vez pelos receptores que interatuam, têmse revelado eficazes na gestão de conteúdo. Por isso a abordagem exclusivamente sociológica a esse processo que não integram uma dimensão textual e discursiva, se faz de uma forma extremamente redutiva. A chamada Escola Nórdica da midiatização estabeleceu um grande debate sobre a influência dos meios na mudança social, cunhando a distinção entre Media-

\footnotetext{
${ }^{3}$ NT: prosumer conforme Alvin Toffler, 1980.
} 
EID\&A - Revista Eletrônica de Estudos Integrados em Discurso e Argumentação, Ilhéus, n. 16 esp. "Discurso e argumentação na política latino-americana, set.2018.

centric e Media-centered (HEPP, 2014; LUNDBY, 2014) que já havia sido teorizada por Eliseo Veron na década de 1980. Mas, em nível político e não somente acadêmico, uma primeira consequência que salta aos olhos é a debilidade dos partidos tradicionais para integrar em profundidade essas novas práticas.

Temos visto como os meios de comunicação instalaram-se na sociedade não somente como uma gigantesca indústria de conteúdo, mas, sobretudo, como condição da inteligibilidade social. Eliseo Veron formula sua célebre distinção entre sociedades midiáticas e sociedades midiatizadas a partir de sua análise do acidente da central atômica de Three Miles Island em 28 de março de 1979 que teve cobertura das mídias de todo o mundo (VERÓN, 1981). Considerado na França entre os construtivistas radicais, Veron afirmava no prólogo da edição espanhola de 1987 (III, IV) "Os meios não copiam nada, produzem realidade social [...]".

Qual é então a especificidade da mediação Web 2.0? Para Veron é a especificidade técnica do dispositivo, com seu alcance e velocidade de circulação de textos, somada à busca "inteligente" que dispõe o Google: "A WWW comporta uma mutação das condições de acesso de atores individuais à discursividade midiática, produzindo transformações inéditas nas condições de circulação" (VERON, 2015, p.14).

\section{O surgimento de La Republique en Marche! (A República em Marcha!)}

Que dimensões e variáveis devemos mobilizar para analisar os sites dos atores políticos? Surge a figura de Emmanuel Jean-Michel Frédéric Macron, jovem político de 39 anos, ex-ministro da Economia, Recuperação Produtiva e Assuntos Digitais do governo de F. Hollande, especialista em mecanismos financeiros por ter trabalhado no Banco Rothschild. Macron deu um giro inesperado, renunciando em 30 de agosto de 2015 para fundar em 6 de abril de 2016 seu movimento En Marche!, declarando sua intenção de ser presidente. 
EID\&A - Revista Eletrônica de Estudos Integrados em Discurso e Argumentação, Ilhéus, n. 16 esp. "Discurso e argumentação na política latino-americana, set.2018.

Figura 2 - Declaração de 16/11/2016 na rede. Macron “Rejoignez-nous” (Juntemse a nós)

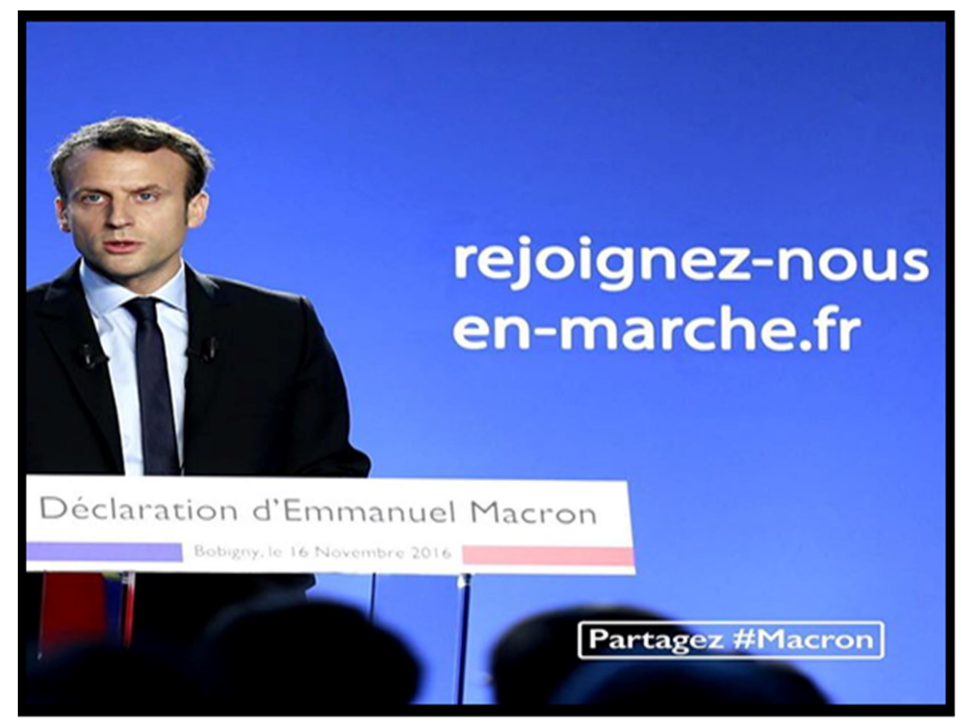

A comunicação de Macron foi muito elaborada e por vezes complexa. Definida como uma "comunicação jupiteriana" e também “crística" em referência ao seu gesto recorrente de começar e terminar os encontros abrindo os braços em sinal de recepção a todos aqueles que querem se somar ao movimento. Esteve integrada pelos meetings (encontros) à americana, com balões e cores em um cenário de $360^{\circ}$ com a presença de militantes para mostrar o espírito de equipe seguindo o modelo de Obama; pelas marchas dos aderentes por toda a França, em operações de timbreo ${ }^{4}$ e também em praças, mercados e lugares públicos, e, sobretudo, incitando a participar da elaboração do programa do candidato. O slogan do movimento Em Marcha! indicava um programa narrativo com uma pragmática específica: marchar, ação essencialmente individual, mas que se pode se tornar coletiva até fazerse multidão, como ficou provado na história com a Grande Marcha de Mao ou a Marcha de Ghandi. Marchar implica sempre em um objetivo, senão, se está passeando ou perambulando. Revelou-se, então, em uma excelente síntese entre uma ação militante individual e a prática comunicativa coletiva específica: fazer sair à rua o cidadão para se juntar aos outros.

Por último, o uso intensivo da comunicação por SMS para os eventos do movimento com mensagens do tipo "se está em tal bairro poderá comparecer a tal encontro..." tomando como modelo as formas atuais de encontros e

${ }^{4}$ NT: Timbreo: Termo que designa o ato dos candidatos ou governantes de visitarem as casas de seus eleitores na Argentina. 
EID\&A - Revista Eletrônica de Estudos Integrados em Discurso e Argumentação, Ilhéus, n. 16 esp. "Discurso e argumentação na política latino-americana, set.2018.

pontos de encontro entre os mais jovens. A concepção e a implementação de um rico site na web foram centrais para a estratégia enunciativa de consolidação de um coletivo de identificação muito específico denominado o povo da web.

Figura 3 - Encontro de Paris em 10/12/2016. A revolução em Marcha e o gesto "crístico" de Macron.

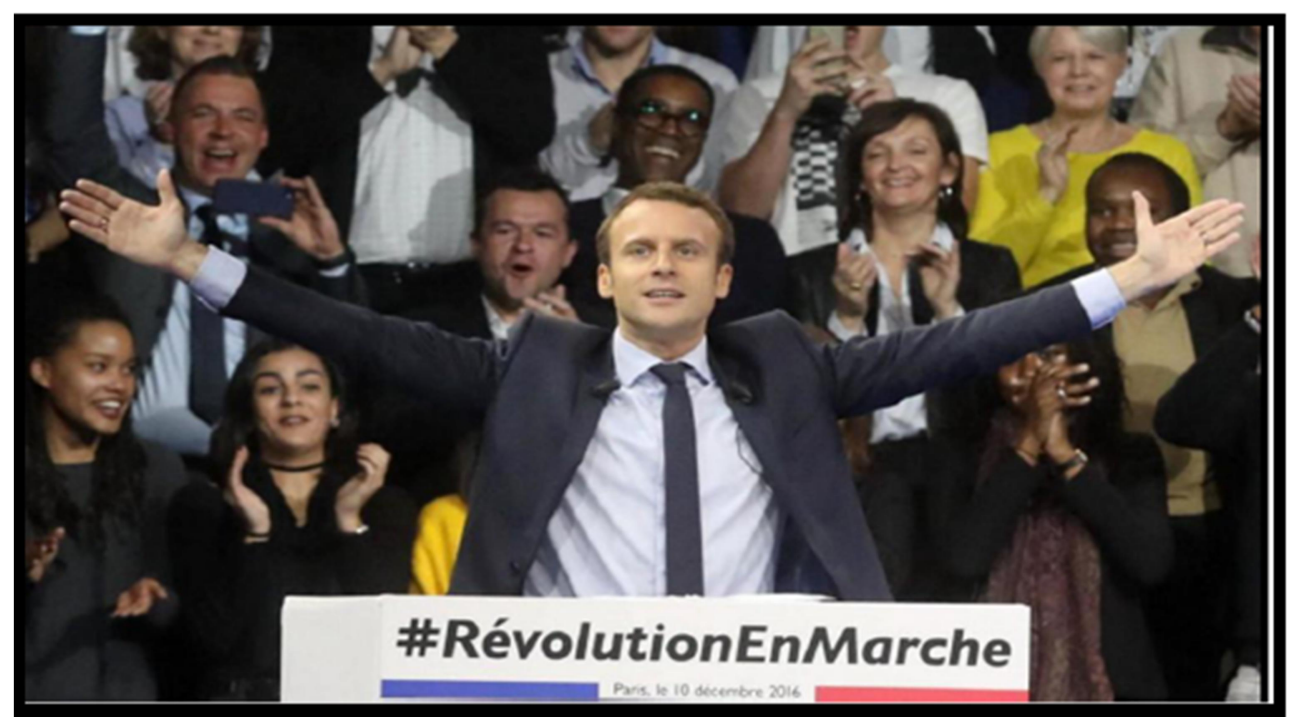

A construção do relato macroniano é de um homem que chega "de fora" da esfera política e em consequência não está contaminado por ela. Uma construção ficcional porque Macron é um produto puro da formação meritocrática das elites do governo francês. A storytelling leva em conta o ceticismo, desconfiança e cansaço da sociedade, ante a classe política e seu profundo desprestígio. As denúncias de seus adversários políticos tratando de fixar a figura de Macron à do impopular presidente foram infrutuosas, mostrando o êxito que foi a estratégia enunciativa de se colocar de "fora" do mundo político, em uma conexão direta sem mediações com seus eleitores. Macron construiu um contrato fundado na ação emblemática de marchar e na prática comunicativa de intercâmbio e de compartilhar (trocar/compartilhar), as ações que potencializaram seu site da web.

Macron forma um pequeno grupo de militantes e seguidores e no mês de maio de 2016 lança Revolución En Marche (Revolução em Marcha), uma marcha de militantes que percorrem a França para recolher mais de cem mil testemunhos de gente comum. $\mathrm{O}$ material recolhido lhe permite ir escrevendo 
EID\&A - Revista Eletrônica de Estudos Integrados em Discurso e Argumentação, Ilhéus, n. 16 esp. "Discurso e argumentação na política latino-americana, set.2018.

sua plataforma a partir das demandas concretas dos entrevistados, recordando o método da escrita coletiva dos Cahiers de Doléances que se formaram durante a Revolução Francesa.

Isso não é um feito menor na construção do povo da web porque a escrita coletiva da plataforma política revela mais da prática de mushup ${ }^{5}$.

Acusado de falta de ideologia política e de superficialidade, pressionado pela mídia para se definir rapidamente, porque os outros candidatos já haviam apresentado suas plataformas, Macron continuou com seu método de consulta e perseverou na imposição imutável de um timing próprio que se resultou exitoso.

Figura 4: O povo da web em marcha: colorido e com mistura de idade, classe social e cultural.

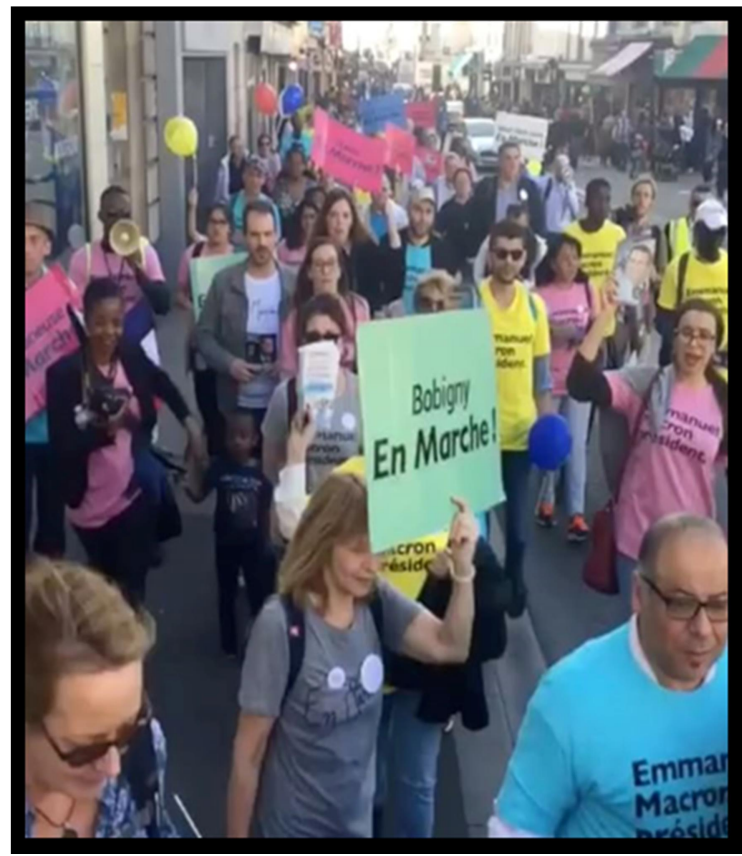

Percebido como um elétron livre da política, o establishment no início não o considerou seriamente - nem sequer o consideraram um oponente direto, ao ponto de os programas de televisão ao qual fizemos referência não o terem incluído em suas primeiras transmissões. Mas, logo se tornou

\footnotetext{
${ }^{5}$ NT. Designa mistura. Na música, referente à mistura de músicas típica da música eletrônica. Na tecnologia, designa a integração de diversos serviços distintos no intuito de fornecer um só serviço, diferentes serviços que podem funcionar simultaneamente.
} 
EID\&A - Revista Eletrônica de Estudos Integrados em Discurso e Argumentação, Ilhéus, n. 16 esp. "Discurso e argumentação na política latino-americana, set.2018.

indispensável na paisagem midiática francesa, com sua atrativa imagem de político jovem e sua romântica história de amor que cativou o público.

\section{Por que nós somos um povo?}

Em 16 de março, aparece em seu site um espaço intitulado "Por que nós somos um povo?" no qual Macron trata das causas do imobilismo francês. Frente à xenofobia e ao racismo, a pedagogia macroniana busca construir um coletivo não excludente e não polêmico. Essa mensagem teve 1.896 .963 curtidas e 2.036. 326 seguidores.

Figura 5 - Por que nós somos um povo?

16 mars
Pourquoi nous sommes un peuple
En quoi sommes -nous un peuple ? Depuis plusieurs années, des groupes et des responsables
politiques nous empêchent de répondre à cette question vitale pour la survie du projet français.
Les uns font leur nid au creux de notre identité. Leur premier combat fut de stigmatiser ceux
qui ne leur ressemblaient pas et leur première victoire fut la naissance du ministère de IIdentité
nationale...
1896963 personnes aiment ça
2036326 personnes suivent ce lieu

Qual é o povo que Macron está construindo na web? Um povo desterritorializado e onipresente no espaço virtual, mas concreto em sua representação figurativa, com uma militância de contato. Esta construção se realiza em vários níveis heterogêneos de figurativização: com os discursos em comícios, com a representação figurativa de seus participantes, com a estratégia de agregação ("rassambler") de seu site, com a delegação de continuação da ação nos sites pessoais dos adeptos e com a circulação no Twitter ou Facebook, como hashtag ou trending topics.

O site do movimento é um site dinâmico e rico que segue as tendências da web: conteúdos variados, diferentes tipos de discursos e de intervenções, com uma forte fonte agregativa ("Vamos, venham conosco") e uma imagem otimista dada pela juventude de seus participantes e a abundância de cores. Um site não excludente. 
EID\&A - Revista Eletrônica de Estudos Integrados em Discurso e Argumentação, Ilhéus, n. 16 esp. "Discurso e argumentação na política latino-americana, set.2018.

Figura 6 - Os jovens com Macron. "Juntemo-nos para mudar a França”

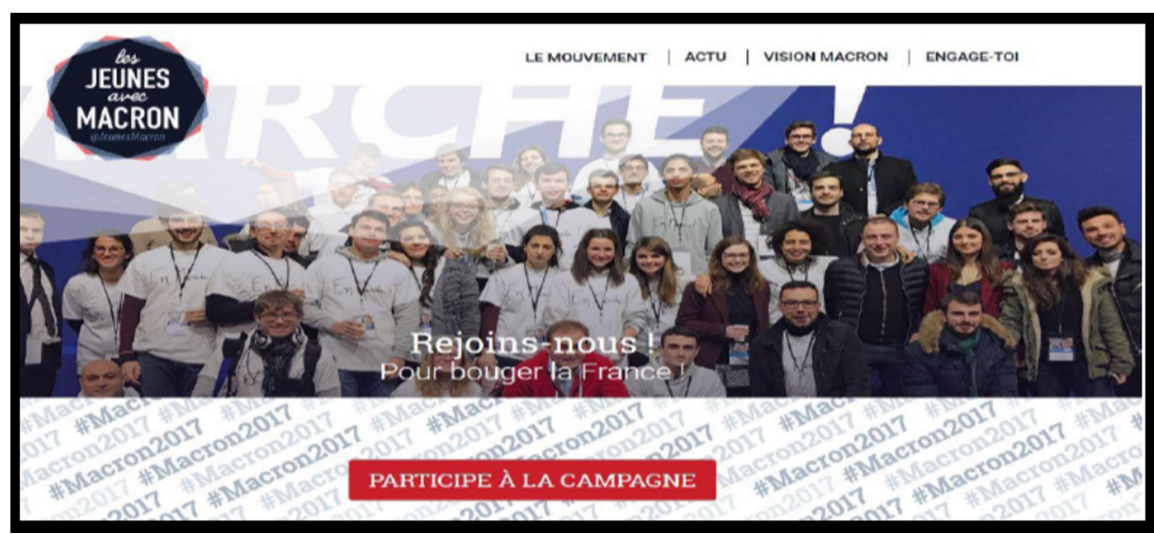

Existe uma enciclopédia midiática de receptor (ESCUDERO CHAUVEL, 2017), e a paleta macroniana faz recordar as publicidades das primeiras campanhas de United Colors of Benetton: a unidade na diferença. Aqui a unidade se dá nas ações que são realizadas em conjunto e as que apelam: marchar, reunir-se, discutir fora dos meios tradicionais. É no coletivo de identificação que constroem: os jovens com Macron.

Uma verdadeira pragmática da ação política na web se põe também em marcha: a rede militante virtual com nova forma de participação, as instruções de uso da página; os alertas nos celulares para dirigir-se aos locais e apoiar as ações, a comunicação online sai do quadro para regular as formas de encontro no mundo off-line e suas distâncias:

(a) A utilização de avatares como militantes, com nome, sobrenome e foto, dando a ilusão de uma identificação possível e um efeito de verossimilhança.

Figura 7 - Avatar, macro-encunciador e enunciação enunciada.

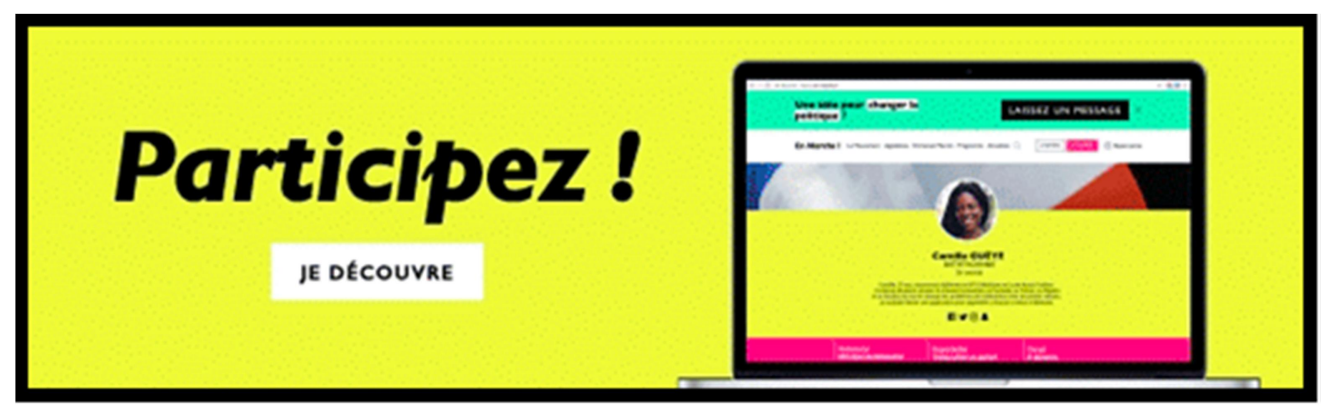

A figura 7 é complexa porque condensa a práxis enunciativa do site: a mensagem se escreve dentro de uma instrução definitiva e urgente: Participe! 
EID\&A - Revista Eletrônica de Estudos Integrados em Discurso e Argumentação, Ilhéus, n. 16 esp. "Discurso e argumentação na política latino-americana, set.2018.

Mas ao mesmo tempo introduz-se uma representação da fala do destinatário como um co-enunciador (Eu descubro); a inscrição da ação aparece subjetivada como práxis pessoal e assumida. Por último, a inscrição do avatar reforçada pelo recurso visual da caixa de texto, pela imagem e pelos dados, que remetem a um externo do texto. O avatar se torna assim exemplo e ligação do povo da web e longe de ser causa de uma verdade exterior ao texto (a foto), torna-se a cautela de uma nova práxis política interna do dispositivo (Je découvre). E este é o verdadeiro papel do site: estruturar uma tomada de palavra, seja pelo formato técnico da inserção das pequenas caixas, seja pelos marcos propostos pelo desenho, seja pelo programa narrativo em que se enquadra nossa prática: informo-me, faço adesão, comento, doo, etc. Tudo enquadrado por um macro enunciador que nos ordena participar.

Quando falo da especificidade do dispositivo de enunciação digital, faço referência a que este é um conceito central da construção da relação entre destinador e destinatário de mensagem porque é um mecanismo de mediação. A comunidade "Em Marcha" é basicamente a construção de uma experiência identitária online

Estamos na presença de um dispositivo de mediação técnica (o suporte de site) que determina pelo seu pré-formato as possibilidades de sua manifestação discursiva ou esta é independente do suporte? Este circuito ideal ao qual o dispositivo técnico (Internet) e o dispositivo discursivo (o site) nos confrontam é endógeno: a controvérsia, as notícias falsas, os rumores, as negações e todas as ações comunicativas que também participam da esfera pública, estão fora do site, porque representa uma superfície sem arestas, de uma comunhão ideal que não colide com o mundo off-line. O povo da web adere, e até pode discutir, mas é basicamente um internauta e um leitor modelo.

Finalmente, também sucumbi à fascinação Macron e me inscrevi como aderente ao La République en Marche!, no início do mês de abril de 2017. Esta observação participativa me permitiu descobrir o segundo nível ao qual o site nos habilita apenas atravessando a fronteira do espelho. Como no mundo de Alice, os aderentes recebem outro tipo de mensagens e entram em outro mundo. 
EID\&A - Revista Eletrônica de Estudos Integrados em Discurso e Argumentação, Ilhéus, n. 16 esp. "Discurso e argumentação na política latino-americana, set.2018.

Figura 8 - Nominação: jogo enunciativo entre o nós exclusivo e o você

OUI, vous

Lucrecia,

Si vous avez, comme nous, l'envie et l'ambition de vous investir dans la vie citoyenne, de lancer un projet, de faire quelque chose de concret: remplissez votre profil sur le site d’En Marche (avec ou sans diplôme !) et mettez en avant vos compétences.

N'hésitez plus. C'est à vous de jouer.

L'équipe de La République En Marche !

Fonte: E-mail pessoal.

Reconheço que tive um sobressalto quando recebi este e-mail. A enciclopédia midiática me recordava a publicidade que acabara de receber da Orange (empresa de telefonia, internet e TV) para me dizer que sou uma cliente privilegiada. A progressão na personalização é uma estratégia de contato. Como no filme "Mensagem para você"6, encontrei em minha caixa postal uma mensagem do responsável pelo movimento que me oferece a possibilidade de formar-me como cidadã. .

\section{A personalização extrema: a carta manuscrita}

Que função cumpre a inserção, no site, de uma carta manuscrita logo após a eleição de Macron como presidente? Como sabemos a escrita é um clássico sistema de mediação por meio de signos gráficos para anotar uma mensagem, poder conservá-la e transmiti-la. No caso da carta, com sua indicação de data e lugar de emissão, é um caso de interação mediada, não midiática, já que, não há nenhum dispositivo de visibilidade, salvo quando a carta se torna pública. Esse é precisamente o caso de transformação de uma mediação através de duas operações. Primeiro a inscrição da data, com selo e garantia de veracidade e transparência e segundo, a reprodução no site do LREM que implicava sua circulação imediata no circuito da web. Por sua parte a escrita manuscrita tem o dobro do valor de inscrição de uma mensagem e é prova de autenticidade, ou seja, entra em um dispositivo de veridicção. É,

\footnotetext{
${ }^{6}$ Original: You've Got Mail. EUA, 1998.
} 
EID\&A - Revista Eletrônica de Estudos Integrados em Discurso e Argumentação, Ilhéus, n. 16 esp. "Discurso e argumentação na política latino-americana, set.2018.

portanto, colocando esta carta em relação com o conjunto de indícios que apontamos ao longo do texto que torna a carta manuscrita signo.

A carta tem um objeto, como quando escrevemos um e-mail, está já contaminada pelos mecanismos de escrita da web, e comprovante de autenticidade, é dizer que entra em um dispositivo de verificação, ao ponto que a falsificação de escrita ou assinatura, segundo o caso, pode ser penalizada pela lei e objeto de processo em tribunais.

É dizer, algo está no lugar de outra coisa. Porque as fotos dos avatares, os índices de tempo, a hora e os minutos, a contabilidade dos que leem os comentários, a participação dos que gostam dos textos e os fazem circular, a marca específica do dia em que foi recebida, essa escrita está lá no lugar de outra coisa: o povo da web. Função metonímica por excelência - a parte do todo - a carta manuscrita é, no fundo, uma prova de existência do mundo "real". Sim, há algo além da interação virtual.

Figura 9 - A personalização extrema: a carta manuscrita.

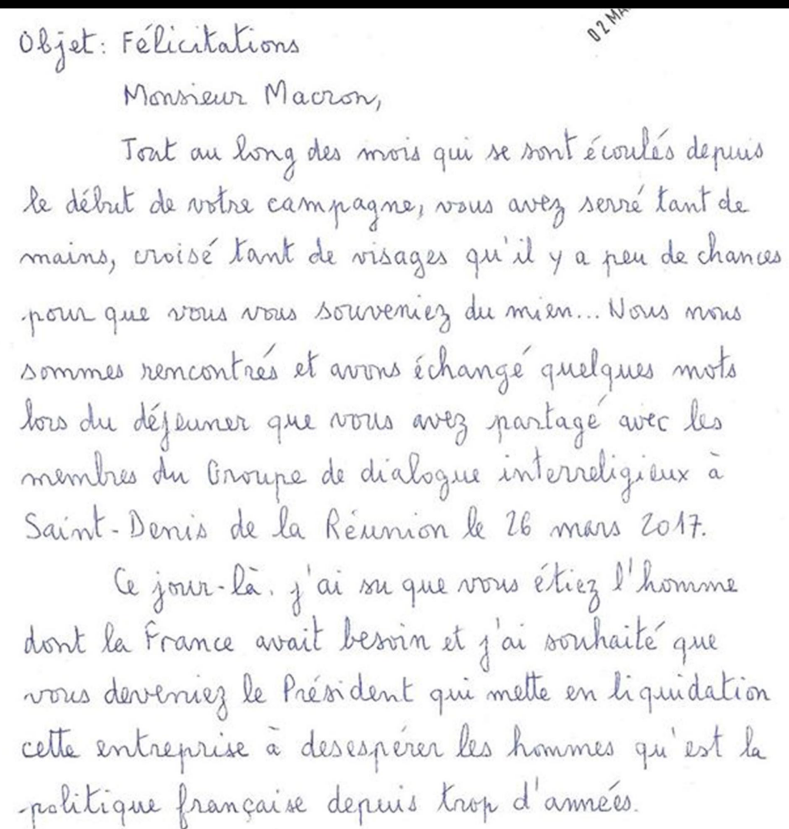

O sistema de escrita alfabética ocidental opõe-se a outros sistemas de escrita como os pictogramas maias ou astecas e os ideogramas chineses. $O$ fato de ser uma caligrafia - ou seja, escrito à mão - mostra não um valor fonético ou conceitual e sim um valor indicial. Escrever à mão é um ato intransitivo, uma atividade específica, autossuficiente e autônoma, como 
EID\&A - Revista Eletrônica de Estudos Integrados em Discurso e Argumentação, Ilhéus, n. 16 esp. "Discurso e argumentação na política latino-americana, set.2018.

marchar havia sido na configuração do movimento En Marche, só que ao entrar no suporte web alcança uma visibilidade coletiva, passando do ato privado ao de visibilidade pública. Se nos detivermos em sua caligrafia, cuidadosa e quase infantil, essa revela a influência da escola primária.

Muito diferente é a escrita de Macron, também reproduzida no site. Aberta, quase um gesto amplo e artístico que ocupa o espaço, o ato de assinar é uma marca pessoal de pertencimento de seu enunciado, e, neste contexto, se torna uma marca de enunciação. Começou-se com um macro enunciador coletivo que dava instruções e sugeria ações, que paulatinamente foi se individualizando com as estratégias dos avatares, até chegar a uma nominação precisa, "eu”, o leitor. Agora se fecha o círculo com uma intervenção forte “Tudo está em suas mãos” delegando o poder. É, não somente, uma responsabilidade coletiva, mas também é todo esse empoderamento sobre o qual tratamos no início do artigo. É a construção de um coletivo cidadão: o povo da web. Essa carta é garantia de transparência, efeito de verdade, opera como uma prova de existência, mas sobretudo, como contrato e compromisso.

\section{Figura 10 - A delegação “Agora, tudo está em vossas mãos”}

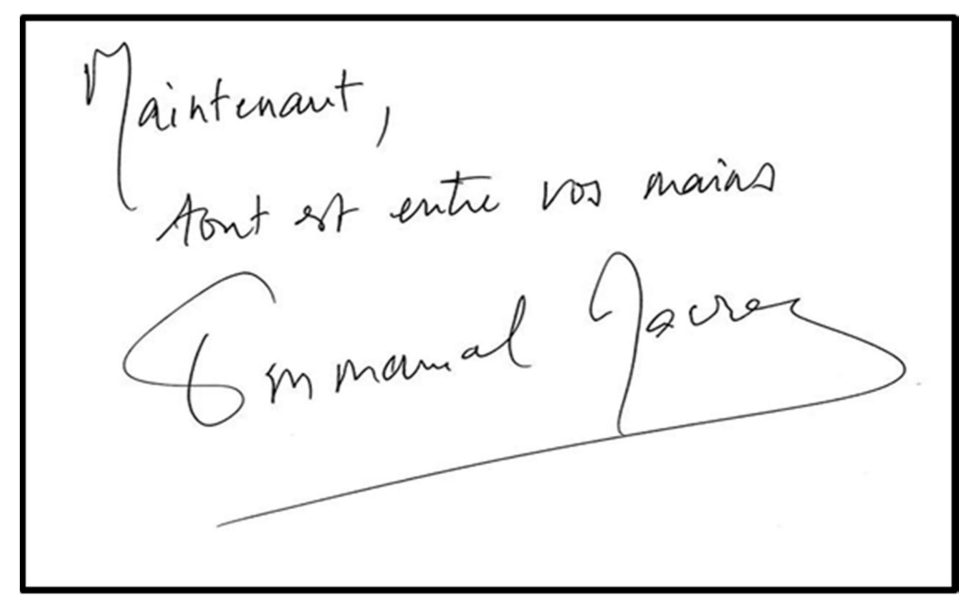

\section{Conclusões}

Começamos essas reflexões com a interrogação se o dispositivo técnico digital condicionava o formato do site e as possíveis organizações da mensagem. Interrogou-se inicialmente em que medida o surgimento das NTIC condiciona o discurso político, as formas de se fazer campanha. Logo após a análise do caso LREM e as eleições de Emmanuel Macron, a pergunta se desloca para como se constrói um coletivo de internautas que se reflete em 
EID\&A - Revista Eletrônica de Estudos Integrados em Discurso e Argumentação, Ilhéus, n. 16 esp. "Discurso e argumentação na política latino-americana, set.2018.

uma ação política concreta. Problema que tem relação com uma clássica pergunta: as plataformas têm o poder de influenciar os seus usuários? Pergunta que se relaciona com a dos efeitos em longo e curto prazo dos meios tradicionais. O problema é complexo e não se esgota aqui: trata-se da articulação entre mecanismos de persuasão discursiva, esfera públicomidiática e plataformas por uma parte; e por outra, receptores, usuários, atores individuais em cujo poder reside, entre outros componentes, 0 exercício da cidadania.

Uma tipologia dos sites da web - como antes existiu uma tipologia dos discursos políticos - é possível se levamos em conta a práxis enunciativa interna”. Aqui as "condições sociais de produção" como denominava Veron, estão evidentes.

Como vimos, as NTIC estão fortemente sujeitas à aceleração da mudança tecnológica e, portanto, ao problema da diacronia: como se desenvolvem os sites e como influenciam na construção da adesão e da confiança, dois componentes essenciais que movem a ação política.

O outro fio condutor para futuras investigações é o da circulação de semioses. No caso de Macron, a dimensão normativa final enquadraria a prática dos atores, seu fazer-fazer e seu saber-fazer. O avatar adquire um saber-fazer, está habilitado a mostrar suas competências e a desdobrar suas performances.

Por que eu disse que se trata de um simulacro da vida política? Não é esta a vida política nos tempos web, hiper-visível e hiper-individualista? Uma participação desterritorializada? É um simulacro porque não há conflitualidade, dimensão crucial do jogo democrático. A superfície e a circulação das mensagens são lisas, sem ruído, sem interferências no canal. Na realidade, mais que um simulacro é uma utopia.

Essa circulação de discursos é a representação ideal e platônica do discorrer na arena pública habermasiana, é através da ideia de intercâmbio comunicativo que se alcançam os consensos e adesões. Utopia comunicativa porque se pressupõe que o povo da web não tem estratégias nem contra estratégias. Sabemos que a enunciação política pressupõe sempre um adversário (Verón 1987:16ss) porque se inscreve em um cenário com outros

\footnotetext{
${ }^{7}$ Atualmente desenvolvo uma pesquisa comparada dos sites da web dos principais candidatos das eleições francesas de 2017. Não basta possuir um site para ser inovador, como demonstra o site de Marine LePen. Laboratório UAB- LAPRECO.
} 
EID\&A - Revista Eletrônica de Estudos Integrados em Discurso e Argumentação, Ilhéus, n. 16 esp. "Discurso e argumentação na política latino-americana, set.2018.

atores, em uma esfera complexa e instável de circulação da palavra pública. Essa oposição entre destinatários do discurso político e contra destinatários não está presente no site LREM. Esse site construiu, pacientemente, um coletivo de identificação inclusivo e não exclusivo, nem polêmico. E, neste sentido, essa construção discursiva foi bem sucedida.

A dinâmica está na produção de uma prática, articulando individualismo e a participação virtual, espaço paradoxal em que se move o povo da web.

\section{Referências}

ECO, Umberto Lector in Fabula. Milano: Bompiani, 1979.

ESCUDERO CHAUVEL, Lucrecia; GARCIA RUBIO, Claudia Democracias de opinión. Medios y comunicación política. Buenos Aires: La Crujía, 2007.

ESCUDERO CHAUVEL, Lucrecia. Puente del Alma. La emergencia de la subjetividad en la superficie mediática. In: CIC Cuadernos de Comunicación y Cultura. Género y Comunicación. Vol5. Madrid: Ediciones de la Universidad Complutense de Madrid. 2000. p.79-99.

ESCUDERO CHAUVEL, Lucrecia. Cultural Studies, Ideology and Media Texts. In: BEARDSWORTH, S.; AUXIER, R. (Ed.). The Philosophy of Umberto Eco. The Library of Living Philosophers Vol. XXXV. Chicago, Ill.: Open Court.2017. p. 657-677.

HEPP, Andreas; HJARVARD, Stig; LUNDBY, Knut. Mediatization: theorizing the interplay between Media, Culture and Society. Media, culture and Society. p.1-11, 2014. httpp://mcs.sagepub.com/content/early/2015/02/16/0163443715573835.

IGARZA, Roberto. Nuevos medios. Estrategias de convergencia. Buenos Aires: La Crujía, 2008.

ROSA, Hartmut. Accélération. Critique sociale du temps. Paris: La Découverte, 2010.

SCOLARI, Carlos. Hipermediaciones. Elementos para una teoría de la comunicación digital interactiva. Barcelona: Gedisa, 2008.

THOMPSON, John B. The Media and Modernity. A social theory of the media. Stranford: Stranford University Press, 1995.

TRAVERSA, Oscar. Dispositivo:¿una noción descriptiva?. In: TRAVERSA, O. Inflexiones del discurso. Cambios y rupturas en las trayectorias de sentido. Buenos Aires: Santiago Arcos Editor/ SEMA, 2014. 
EID\&A - Revista Eletrônica de Estudos Integrados em Discurso e Argumentação, Ilhéus, n. 16 esp. "Discurso e argumentação na política latino-americana, set.2018.

VERON, Eliseo. Construir el acontecimiento. Los medios de comunicación masiva y el accidente en la central nuclear de Three Mile Island. Barcelona: Gedisa, 1987 [1981].

VERON, Eliseo. El discurso adversativo. In: ARFUCH, L. et al. El discurso político. Lenguajes y acontecimientos. Buenos Aires: Hachette, 1987.

VERON, Eliseo. Teoría de la mediatización: una perspectiva semio-antropológica. In: CIC Cuadernos de Información y Comunicación. Ídolos e íconos en la semio-esfera mediática. v.20. Madrid: Ediciones de la Universidad Complutense de Madrid, 2015. p. $173-182$.

WOLTON, Dominique. Penser la communication. Paris: Flammarion, 1999.

Tradução:

Marcos Henrique

Licenciatura Português e Espanhol da Universidade Federal de São Carlos (UFSCar)

Lívia Maria Falconi Pires

Docente do Centro Universitário Central Paulista (UNICEP)

Forma de citação sugerida:

ESCUDERO CHAUVEL, Lucrecia. O povo da web. Enunciação digital e transformação da esfera política. Trad. Marcos Henrique e Lívia Maria Falconi Pires. EID\&A - Revista Eletrônica de Estudos Integrados em Discurso e Argumentação, Ilhéus, n. 16 esp. "Discurso e argumentação na política latino-americana", p. 203-222, set.2018.

Recebido em: 25/07/2018

Aprovado em: 26/08/2018 